\title{
Land-use scenarios for Finnish cut-over peatlands - based on the mineral subsoil characteristics
}

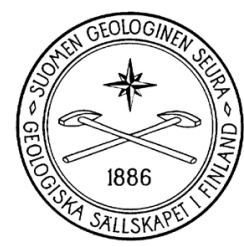

\author{
PäIVI T. Picken \\ Vapo Oy, P.O. Box 22, FI-40101 Jyväskylä, Finland
}

\begin{abstract}
In Finland, peat harvesting sites are exploited down almost to the mineral soil and the properties of mineral subsoil have considerable influence on the suitability for the various afteruse forms. Chemical and physical features of the mineral subsoil must be studied when after-use is planned, to ensure no harmful effects follow. Research on mineral subsoils was carried out on Finnish peat production sites in 1997 - 1998 and 9800 hectares of peat production areas slowly getting exhausted were studied. The cutover area clearly suitable for forestation covered $57 \%$ of the study area. The area well suitable for agriculture or energy crop growing covered 26 - $42 \%$ of the study - depending if boulder-poor tills were included or excluded. Even larger areas might be possible for agriculture if for example remaining peat layer was used for compensating physical features of the mineral subsoil. Approximately II \% was recommended for mire regeneration because of sensitive bottom soils, but much larger areas were possible for mire regeneration. In $9 \%$ of all cases fine mineral subsoils were on pool-forming locations and would this way offer sites best suitable for mire regeneration or even bird sanctuaries. Both $\mathrm{EC}$ and $\mathrm{pH}$ of the mineral subsoils were related to the presence of sulphur. The concentrations of $\mathrm{Ca}, \mathrm{Mg}$ and $\mathrm{K}$ followed the finematerial percentage. Based on this study minimum analysis recommended was for $\mathrm{pH}$, sulphur content and fine material $(<0.06 \mathrm{~mm}$ ) percentage. Other relevant elements were calcium, magnesium and potassium. Different land-use scenarios were created for areas in after-use, released from peat production and in peat production (2004). These scenarios were based on the mineral subsoil suitability for different after-use forms. In these scenarios the total area annual carbon fixation values varied between 0.096 and 0.152 million t $\mathrm{C}^{-1}$, when carbon emissions were not included.
\end{abstract}

Key words: peatlands, cut-away peatlands, land use, soils, chemical properties, physical properties, carbon, deposition, Finland

e-mail: paivi.picken@vapo.fi 


\section{Introduction}

The use of peat energy in Finland expanded to recent levels following the energy crises in the 70's. Now the sites first prepared for harvesting are becoming exhausted. In Finland peat resources have been utilized more thoroughly than for example in North America. In north America quite deep remaining peat layers are possible, these remaining layers on restoration sites have been described for example by Wind-Mulder $\&$ Vitt (2000). In Finland using the bottom peat layers is related to the high quality of the basal peat as energy source. The thin remaining peat layer causes a situation, where the properties of the under-laying mineral soil have to be taken into account when after-use is being planned (Selin, 1999).

The peatland area in peat production in 2004 in Finland was 59300 ha (Silpola, 2004). Majority $(84 \%)$ of the produced peat was milled fuel peat, $8 \%$ was sod peat (fuel), and the last $8 \%$ covered all the non-fuel products including for example horticultural peat and peat for litter. According to a survey carried out by the Association of Finnish Peat Industries area released from peat production in the end of year 2004 was 15671 ha (Silpola \& Tuomanen, 2005). Three biggest after-use forms were forestry (26\%), energy crop production $(14 \%)$ and other agricultural production $(27 \%)$.

Acidity of sulphur-rich soils can be a limiting factor in after-use planning. Sulphide-rich Litorina-zone follows the present coastline and includes former sea bottom sediments. The highest shoreline of the angient Litorina sea is presented in Figure 1 together with the study sites. Dredging of soils creates oxygenating conditions and sulphides may oxidise forming sulphuric acid, iron oxides and hydroxides (YliHalla, 2003). For example in Hirvineva (a former peat production site) the $\mathrm{pH}$ of a small artificial pond decreased in beginning strongly, due to the chemical composition of the mineral subsoil (Siira, 1996). When a bigger lake (bird sanctuary) was built on the same area, a peat layer was succesfully used as insulating material from the beginning (Selin, 1999). According to own earlier study phase $11 \%$ of Finnish cutover peatlands are relatively sulphur rich. In Litorina zone $25 \%$ of cut-over peatlands are relatively sulphur rich. Another area with large sulphur concentrations is a geochemical province called The Lake Ladoga - Bothnian Bay zone (Picken, 2005).

According to Aro \& Kaunisto (1997; 1998) mineral subsoils have an effect on tree growth rates and the proportion of fine material in the mire bottom sediment should be taken to consideration. When the amount of fine material particles (particles smaller than $0.06 \mathrm{~mm}$ ) was less than $15-20 \%$ Aro and Kaunisto (1998) measured weaker forest growth compared to that on finer grained sediments. According to own earlier study phase $15 \%$ of mineral subsoils were coarse grained and $24 \%$ of them were relatively compact to allow agriculture or forestry development (Lötjönen et al., 2002). Mineral subsoils were classified compact if the fine material percentage was higher than $90 \%$. Also the presence of boulders in tills can have effect on after-use because of for example difficulties in machinery use.

In own earlier study phase (Lötjönen, 2004) $57 \%$ of studied cut-over peatlands were well suited for forestry based on both physical and chemical features of the mineral subsoil. The area clearly suitable for agriculture, horticulture or energy crop growing covered $26 \%$. The number would have been larger if tills were also included and the presence of boulders ignored.

In Finland mire regeneration is usually understood as reflooding the site and allowing the natural development of mire vegetation. In current after-use statistics also the more complicated constructions for bird sanctuaries are included to this category. Forestation is usually a deliberate act with adjusting the groundwater level with ditches, planting trees, fertilising and possibly even treating the soil surface - however natural forest development is also part of this category in after-use statistics. Energy crop growing is usually understood as Canary grass production.

Mean LORCA (long term rate of carbon accumulation) for pristine mires in Finland is $22.6 \mathrm{~g}$ 
$\mathrm{C} \mathrm{m}^{-2} \mathrm{yr}^{-1}$ (Tolonen \& Turunen $1996 \mathrm{a}$; b; Tolonen et al., 1996). In the same range fits also a later published study of Haukkasuo in Finland, where LORCA was $19.1 \mathrm{~g} \mathrm{C} \mathrm{m}^{-2} \mathrm{yr}^{-1}$ (Mäkilä, 1997).

Different after-use forms are likely to affect on the future carbon fluxes. Roderfelt et al. (1994) have measured carbon accumulation of $64 \mathrm{~g} \mathrm{C} \mathrm{m}^{-2} \mathrm{yr}^{-1}$ on a mire regeneration site and Tuittila et al. (1999) 64.5 $\mathrm{g} \mathrm{CO}_{2}-\mathrm{C} \mathrm{m}^{-2} \mathrm{yr}^{-1}$ in early stages of mire regeneration. These rates are quite similar to the recent apparent rate of carbon accumulation (RERCA) in Finnish natural mires, ranging from 40 to $81 \mathrm{~g} \mathrm{C} \mathrm{m}^{-2} \mathrm{yr}^{-1}$ (Tolonen $\&$ Turunen,1996a, Pitkänen et al. 1999). The dry mass accumulation of a regrowth layer in a North-American mire ranges from $120-430 \mathrm{~g} \mathrm{~m}^{-2} \mathrm{yr}^{-1}$ (Tolonen et al., 1985). Approximately half of peat accumulation can be estimated to be carbon (Virtanen et al., 2003). Selin (1999) has calculated carbon accumulation rate $90 \mathrm{~g} \mathrm{C} \mathrm{m}^{-2} \mathrm{yr}^{-1}$ for forested after-use sites, based on forest growth values by Kaunisto and Aro (1998). This value was based on stem and branch wood production only, with carbon content coefficient 0.5. Lohila et al. (2004) have published range $90-210 \mathrm{~g} \mathrm{C} \mathrm{m}^{-2} \mathrm{yr}^{-1}$ based on same reference. Estimated range for carbon accumulation for Phalaris growing is $250-360 \mathrm{~g} \mathrm{C} \mathrm{m}^{-2} \mathrm{yr}^{-1}$. (Puuronen et al., 1998; Selin, 1999). Huttunen et al. (2004) have estimated uptake of carbon $300-600 \mathrm{~g} \mathrm{C} \mathrm{m}^{-2} \mathrm{yr}^{-1}$. In this study total carbon gain was over $600 \mathrm{~g} \mathrm{C} \mathrm{m}^{-2} \mathrm{yr}^{-1}$ in an optimal case and carbon loss of over $100 \mathrm{~g} \mathrm{C}$ $\mathrm{m}^{-2} \mathrm{yr}^{-1}$ in a high respiration-low production case. In the case of energy crop production it is relevant to notice, that part of the accumulated carbon is going to be used for energy production.

The primary purpose of this study was to describe the land-use limitations of the cut-over peatlands related to the mineral subsoils. The assumption was that these limitations exist in large scale (they already had been detected in many case studies). Also more information of the chemical and physical features of the mineral subsoils was needed for creating (company-internal) work instructions for after-use planning. Another purpose was to make general scenarios of the land-use split between different land-use forms. Pre- dicting land-use was needed for planning both economical and environmental aspects of the after-use. Estimations of carbon accumulation levels related to these predictions were also needed to support large scale planning.

\section{Material and methods}

\section{I. Study sites}

The study of mineral subsoils under peat layers was carried out on 9800 ha of peatlands in Finland, in 1998-1999, 54 different studied sites are presented in Figure 1. All these studied sites were or had been in peat production.

Study sites were chosen from among such production areas operated by Vapo Oy where peat production had ended within last few years or was ending within the next few years. From this group the production sites with the largest percentages of area owned by the peat producer were included in this research. In these areas the producer was more able to choose the after-use form.

\subsection{Field and laboratory methods}

A new mapping practice was created. Research line orientations were mostly chosen to cross the previously known glacial flow directions. Close to the ice margin formations (end moraines etc.) research line orientation was chosen to be the same as latest glacial flow direction. These line orientations were likely to cross most of the different subsoil zones lying under the peat. Information of glacial flow directions was read from general geological maps in Geochemical Atlas of Finland (Koljonen, 1992). Subsoil surface topography was defined using maps, existing research material (for example from Geological Survey of Finland) and earlier ground penetrating radar profiles.

For 100 hectares of peatland $3-5$ research lines were used depending on the shape of the area. The normal sampling interval was $100 \mathrm{~m}$, though a 50 $\mathrm{m}$ sampling interval was used when the mineral subsoil was very heterogenous. A $200 \mathrm{~m}$ sampling interval was used on a few very large production sites 


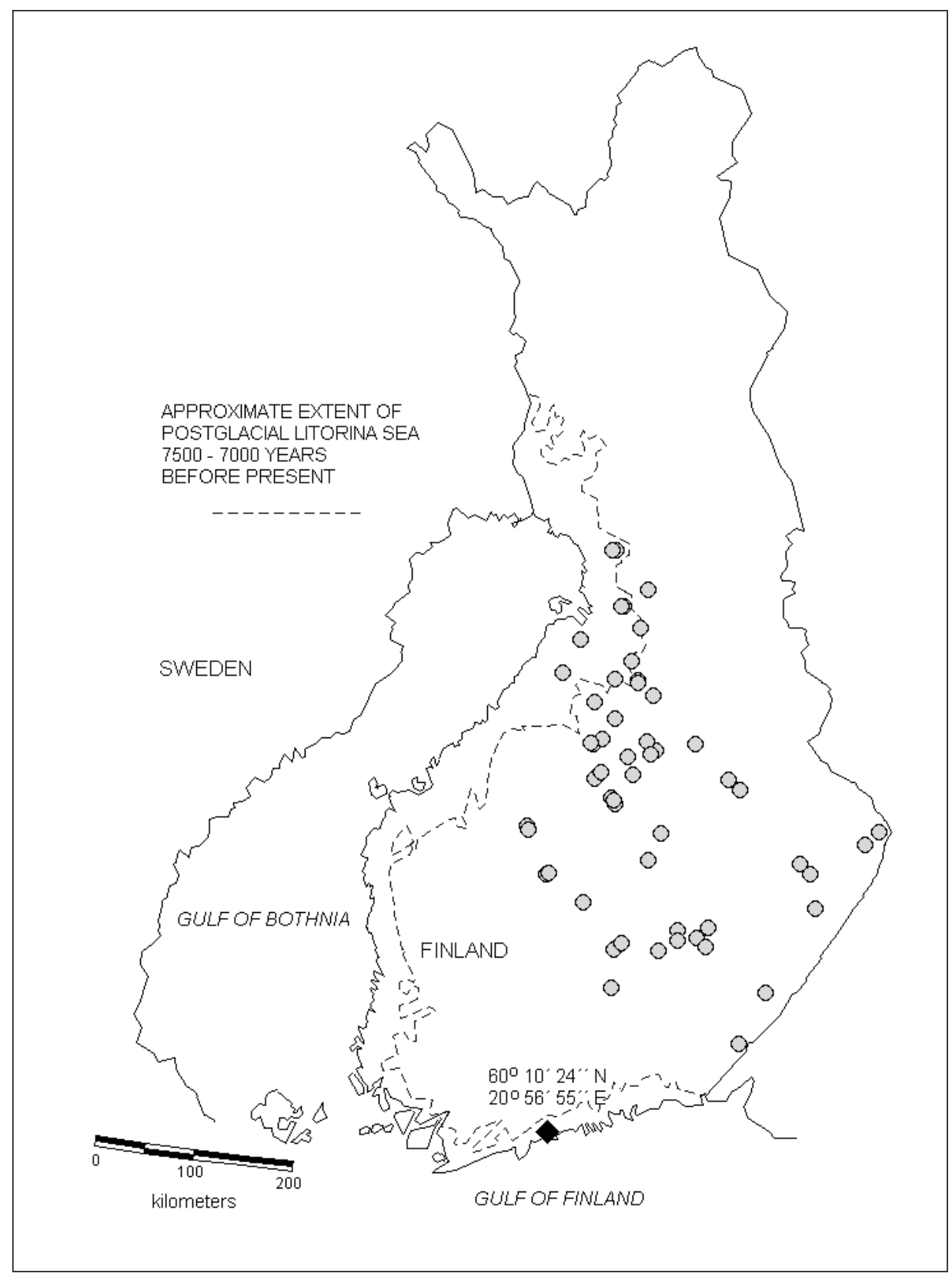

Fig. I. Location of the study sites in Finland. The approximate extent of the ancient Litorina sea is drawn to the map according to Eronen \& Haila (1990).

that were studied earlier with ground radar. Sampling depth was $10-30 \mathrm{~cm}$ under the surface of the mineral subsoil. Diameter of the drill core was $10 \mathrm{~cm}$ and drilled samples were nearly undisturbed. Till with big boulders could not always be drilled and was sampled from the same depth with a shovel. All the samples were studied under field conditions and part of the samples were studied in the laboratory. Field studies included classifying material to till and different sorted sediments (clay, silt, sand and gravel). The presence and the size of boulders were documented. Laboratory studies referred to in this article included the anal- 
ysis of grain size distribution and chemical features of the mineral subsoil. Grain size distribution was tested by dry sieving and areometer analysis. $\mathrm{pH}$ analysis was done according to EN 13037:1999 and electrical conductivity according to EN 13038:1999 (methods accepted by European committee for standardization). Organic matter was analysed according to EN 13039:1999. $\mathrm{P}, \mathrm{NO}_{3}-\mathrm{N}, \mathrm{NH}_{4}-\mathrm{N} \mathrm{S}$ and Fe were analysed from water solution (EN 13652:2001). In practise the water soluble analysis, $\mathrm{pH}$ and $\mathrm{EC}$ are done in $1+5$ solution ( 1 one part of sample and five parts of deionised water). $\mathrm{Ca}, \mathrm{Mg}$ and $\mathrm{K}$ (exchangeable elements) were determined by modified EN 13651. Instead of extracting the samples with calcium chloride/DTPA (CAT) $0.5 \mathrm{M}$ ammonium acetate $(\mathrm{pH}$ 4.65) was used. Nutrient analysis was carried out with atomic absorption spectrophotometer.

\subsection{Classification and statistical analysis methods}

Mire bottoms were classified based on their suitability for different after-use forms. Different categories were based on fine material percentage and sulphur content. According to Aro \& Kaunisto (1998) forest growth is weaker when the amount of fine material (particles $<0.06 \mathrm{~mm}$ ) is under $15-20 \%$ compared to a higher content of fine particles. In this mineral subsoil study $15 \%$ was used as a lower limit value for both forestry and agriculture. Gravel $(2-20 \mathrm{~mm})$ and coarser sands $(0.2-2 \mathrm{~mm})$ are known to have poor water and nutrition economy also in agriculture (Heinonen et al., 1992). Upper limit 90 \% of fine particles was chosen for a pre-study (Lötjönen, 1999, Lötjönen et al., 2002). It was based on the grain size distribution data in the research material (pre-study). This limit was most likely to rule out soil types with grain size class $0.002-0.02 \mathrm{~mm}$, which is generally known to be difficult in cultivation (Heinonen et al., 1992). It was important to keep classification simple and base all grain-size related limit values on the percentage of $0.06 \mathrm{~mm}$ grains. The risk of ruling out also good clay soils does exist in this classification, but on the other hand also clays can be problematic in culti- vation (Heinonen et al., 1992). According to the prestudy clays were also commonly found in the deepest parts of the peatlands (Lötjönen, 1999; Lötjönen et al., 2002), in areas difficult to drain. The same upper limit for fine material percentage was used for both agriculture and forestry.

"Relatively sulphur rich" sediments were defined in a statistical way (Eq.1), to describe mineral subsoils with capacity to produce acidity (Picken, 2005).

(Eq. 1)

$\left[\mathrm{pH}^{*}<\left(\right.\right.$ average $\mathrm{pH}^{* *}-$ standard deviation of $\left.\left.\mathrm{pH}\right)\right]$

and

[sulphur concentration ${ }^{* * *}>$ average sulphur concentration $\left.^{* * * *}\right]$

where

${ }^{*} \mathrm{pH}$ is the individual object $\mathrm{pH}$.

** Average $\mathrm{pH}$ is the average $\mathrm{pH}$ from this same research material.

*** Sulphur concentration is the individual object sulphur concentration.

**** Average sulphur concentration is the average sulphur concentration from this same research material.

High sulphur concentration and low $\mathrm{pH}$ were considered as a classification limit for building bird sanctuaries, because of the effects on water quality. Relatively sulphur rich sediments were ruled out. Topography and the distribution of different mineral subsoil types were preferred to be pool-forming. Poolforming in this study means not just a depression, but also fine and compact sediments forming a lining in the middle of the basin. Sulphur was also seen as a limitation for agriculture and forestry, especially because of the quality of drainage waters.

No limit values were applied for mire regeneration, because the needs for disturbing the soil are 
small and topography usually is suitable enough. After removing part of the peat layer the sites are usually lower than their surroundings. In practice mire regeneration was mainly recommended for areas with very fine and compact mineral subsoil.

The Bivariate Correlations procedure of SPSS 13.0 was used for computing Pearson's correlation coefficients when analysing the relationships of different features in mineral subsoils.

\subsection{Tools for calculation}

Some land-use scenarios were created for the discussion of the future after-use of peat production sites. Land-use scenarios were created for the total hectares of the current peat production area, together with released areas waiting for final after use form.

The first scenario was completely based on the assumption that the percentages of the land-use forms stayed the same as they are. In the second scenario any area suitable for forestry with any reasonable techniques was used for forestry. In the third scenario all areas suitable for agriculture with any reasonable techniques were taken to Canary Grass production. In the fourth scenario only areas best suitable for first energy crop production and secondarily for forestry were taken for these after-use forms. All the other areas were taken for mire regeneration. In all of these cases "economical use with reasonable techniques" meant that all areas except areas with fine mineral subsoils in pool-forming locations and areas with relatively sulphur-rich mineral subsoil would be taken to economical use. Possibility of other agricultural use of cut-over sites than energy crop production in future was not separately calculated. Scenarios are presented in Figure 4.

Different coefficients for carbon accumulation were collected from literature to estimate carbon accumulation in different land-use scenarios. The used carbon accumulation value for mire regeneration in the calculations was $64 \mathrm{~g} \mathrm{C} \mathrm{m}^{-2} \mathrm{yr}^{-1}$. This value was an average of studies by Roderfelt et al. (1994) and Tuittila et al. (1999). The rate used for average forested after-use sites was $90 \mathrm{~g} \mathrm{C} \mathrm{m}^{-2} \mathrm{yr}^{-1}$, defined by Selin
(1999) and based on Kaunisto and Aro (1998). The carbon accumulation value used for Phalaris (energy crop) in this calculation was $300 \mathrm{~g} \mathrm{C} \mathrm{m}^{-2} \mathrm{yr}^{-1}$ and based on range $250-360 \mathrm{~g} \mathrm{C} \mathrm{m}^{-2} \mathrm{yr}^{-1}$ (Puuronen et al., 1998; Selin, 1999).

\section{Results}

\section{I. General chemical features of mineral subsoils}

Mineral subsoils of cut-over peatlands were very poor in nitrogen and phosphorus. Concentrations of both phosphorus and nitrogen were mostly quite close to the detection limits. Some characteristic features of mineral subsoils are presented in Table 1. Also general nutrient conditions are presented in the same table. Nutrient content (exchangeable $\mathrm{Ca}, \mathrm{Mg}$ and $\mathrm{K}$ ) followed the fine material $(<0.06 \mathrm{~mm})$ percentage of the mineral subsoil. Medians between groups $<15 \%$ and $15-19.99 \%$ of fine material did not differ from each other much, but standard deviation was smaller in the finer group. In the group $20-30.99 \%$ of fine material nutrient medians were already clearly higher - when calcium, magnesium and potassium were being studied. Details related to different grain size groups are presented in Table 2 .

Differences between fine material \% groups were very small when phosphorus, nitrogen and sulphur (water-soluble) were being studied. These are presented in Table 2. The presence of organic matter in the mineral subsoil did not clearly control these concentrations either. Some significant correlations were found between fine material percentage and calcium, $\mathrm{mg} / \mathrm{l}$ (0.69), fine material percentage and magnesium, mg/l (0.59) and fine material percentage and potassium (0.51). A significant negative correlation was found between EC and $\mathrm{pH}$ (correlation coefficient 0.74). Calcium, magnesium and potassium all correlated clearly with each other $(0.72-0.85)$. A significant correlation (0.95) was found between sulphur $(\mathrm{mg} / \mathrm{l})$ and EC. These results indicated that sulphur concentration controlled both $\mathrm{pH}$ and $\mathrm{EC}$ in the mineral subsoils. The presence of organic matter was small due to the sampling depth, and had the 


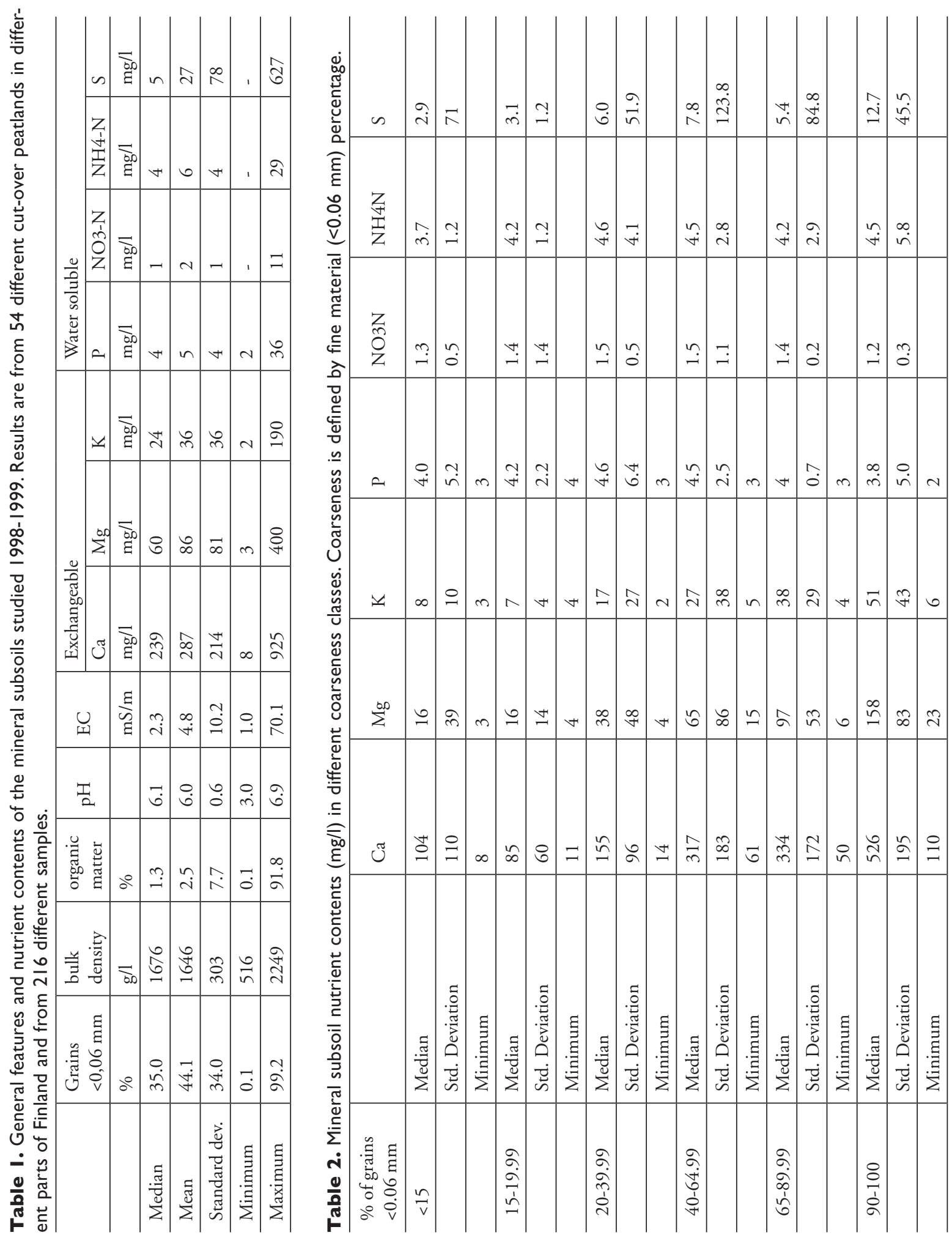


only significant correlation with ammonium-form of nitrogen, 0.16 .

In finest sediments $(90-100 \%$ of $<0.06 \mathrm{~mm}$ grains) the calcium concentration ( $\mathrm{mg} / \mathrm{l}$, exchangeable) was five times the calcium concentration in coarsest sediments ( $<15 \%$ of $<0.06 \mathrm{~mm}$ grains) and the magnesium concentration in the finest sediments was approximately ten times the magnesium concentration ( $\mathrm{mg} / \mathrm{l}$, exchangeable) in the coarsest sediments. Potassium concentration ( $\mathrm{mg} / \mathrm{l}$, exchangeable) in the finest sediments was approximately six times the potassium concentration in the coarsest sediments. Details of this analysis are presented in Table 2. Standard deviations of sulphur were large and not dependent on coarseness. In general the ranges of nutrients were quite large - except phosphorus and nitrogen, which remain relatively low in all samples. Calcium ranged between 8 and $925 \mathrm{~g} / \mathrm{l}$, magnesium between 3 and $400 \mathrm{~g} / \mathrm{l}$ and potassium between 2 and $190 \mathrm{~g} / \mathrm{l}$. Sulphur was under detection limit when lowest and $627 \mathrm{mg} / \mathrm{l}$ when highest. EC ranged between 1.0 and $70.1 \mathrm{mS} / \mathrm{m}$.

\subsection{General physical features of mineral subsoil}

Till had a $27 \%$ share of all mineral subsoils under peat and till covered with a thin layer of sand, silt or clay had a $16 \%$ share. Different sorted sediments had a $57 \%$ share.

Very fine sediments (with $>90 \%$ of grains smaller than $0.06 \mathrm{~mm}$ ) covered $24 \%$ of the area. Coarse sediments (with $<15 \%$ of grains smaller than $0.06 \mathrm{~mm}$ ) covered $15 \%$ of the area. Sediments including under $20 \%$ of grains smaller than 0.06 , covered $21 \%$ of the area. Sediments, that could be called critically coarse, covered $15-21 \%$ of the area.

Approximately $50 \%$ of till under peat layer was relatively boulder-poor. In these till areas the coarsest particles were generally smaller than $20 \mathrm{~cm}$, but small amounts of $<60 \mathrm{~cm}$ boulders were found. Also approximately half of till covered by a thin layer of sorted sediments was similar, relatively boulder-poor. In other types of till boulders with over $60 \mathrm{~cm}$ diameter were largely present and in many cases even $1-2$ meter boulders were present.

More than half (52\%) of all clays were located on probable former lake-forming depressions, where coarser sediments surrounded the clay. Approximately a third (30\%) of fine silts were located on similar sites. Approximately $9 \%$ of all mineral subsoils were very fine sediments (with $>90 \%$ of grains smaller than $0.06 \mathrm{~mm}$ ) located on these pool-forming depressions. None of the relatively sulphur rich sediments (11\% of all studied areas) were located on these pool-forming sites, but they were largely same ones as other very fine sediments.

\subsection{After-use recommendations and limitations related to mineral subsoil}

The share of mire bottoms physically well suited for forestry was $61 \%$, meaning sediments not too coarse and not too fine. This included $4 \%$ of relatively sulphur rich areas. As a conclusion there was $57 \%$ of areas well suitable for forestry. The average fine material ( $<0.06 \mathrm{~mm}$ grains) content in mire bottoms recommended for forestry was $47 \%$.

In a conservative calculation $26 \%$ of the areas studied were well suitable for agriculture, horticulture or energy crop production. If boulder-poor tills were included, $42 \%$ of areas would be well suitable for these purposes. If compensation possibilities related to remaining peat layer were also taken to consideration, the percentage might be even larger. Unsuitable areas were after all a very non-homogenous group including areas with very fine or very coarse mineral subsoil, tills with large boulders and sulphurrich areas.

Relatively fine and compact or coarse mineral subsoils with relatively high sulphur content covered 7 $\%$ of the areas. There was also a $4 \%$ share of the total area with relatively sulphur rich sediments without physical land-use limitations. Together $11 \%$ of all studied areas were relatively sulphur rich. These all were different areas from the areas with fine sediments on pool-forming sites. Mire regeneration does not necessarily demand much disturbing of the min- 


\section{$\%$ of total area}

\section{coarse}

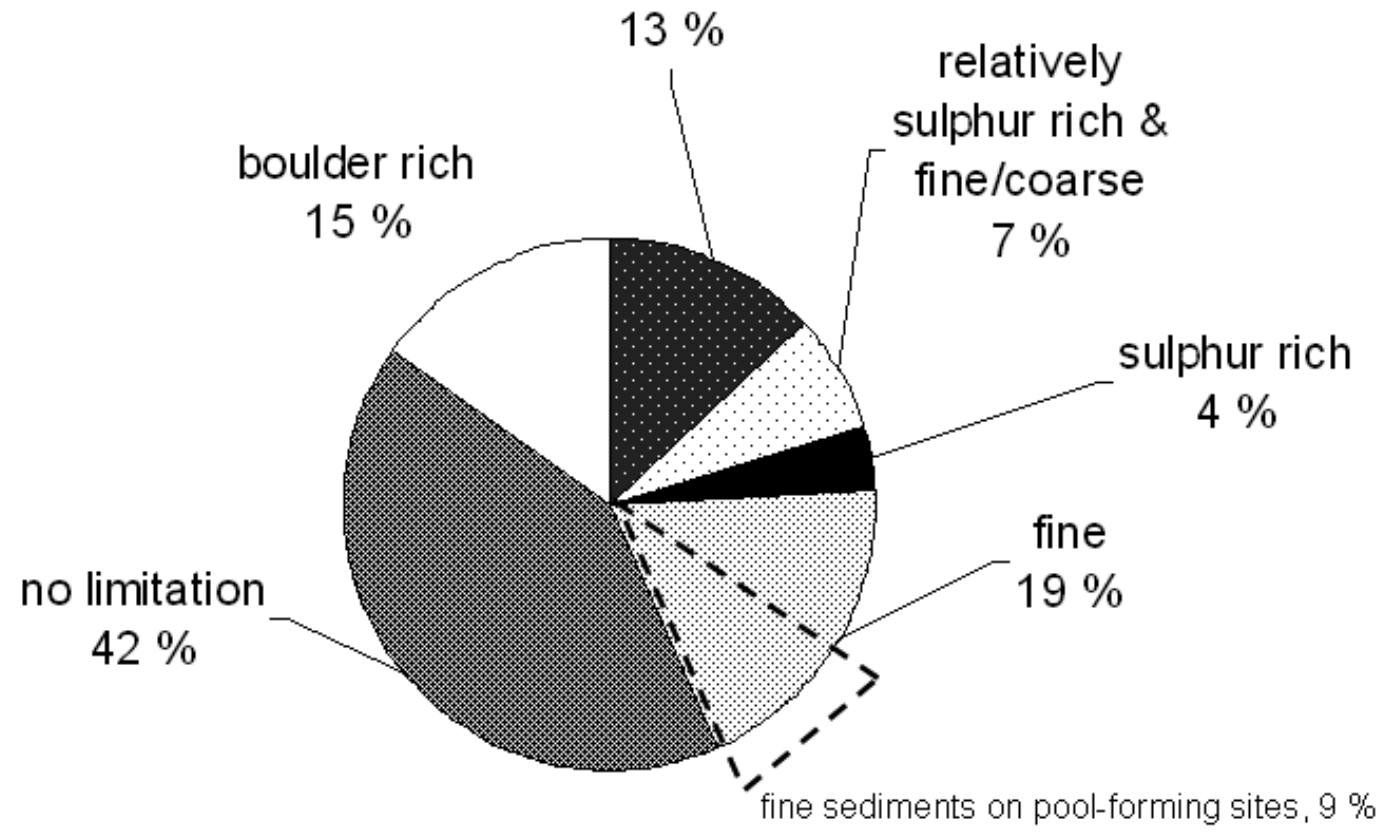

Fig. 2. After-use limitations for Finnish cut-over peat lands.

eral subsoil - so mire regeneration can be recommended also for areas with high sulphur concentrations.

Probable former lake-forming depressions (poolforming sites), where coarser sediments surrounded the fine sediments are areas likely to be flooded or likely to remain quite moist in the end of peat production. These fine sediment areas (likely to be flooded) covered $9 \%$ of all studied areas. Areas like this, poorly suited for economical use, were generally well suited for bird sanctuaries or mire regeneration.

Remaining $23 \%$ of the area includes only fine (10\%) and coarse (13\%) mineral subsoils. No chemical limitations were found on these sites and they were not found on pool-forming sites. Economical use of these is likely to demand special techniques like using more effectively the porosity or cation exchange of the remaining peat layer or fertilization. These sites could also simply be used for mire regeneration. The limitations of after-use are presented in Figure 2 and the recommendations in Figure 3.

\subsection{Land-use scenarios and carbon accumulation calculations}

\subsection{Carbon accumulation in areas already in after-use}

After-use choices are likely to affect on carbon balance. 10876 ha of cut-over peatlands were already in final after-use at the end of the year 2004. Calculated current carbon accumulation for these sites was 0.011 million t $\mathrm{C} \mathrm{yr}^{-1}$. Majority of the carbon accumulation was related to energy crop growing and another large quantity to forestry. Wetlands covered a relatively small percentage of the after-use area (calculated carbon accumulation $\left.156 \mathrm{t} \mathrm{C} \mathrm{yr}^{-1}\right)$. 


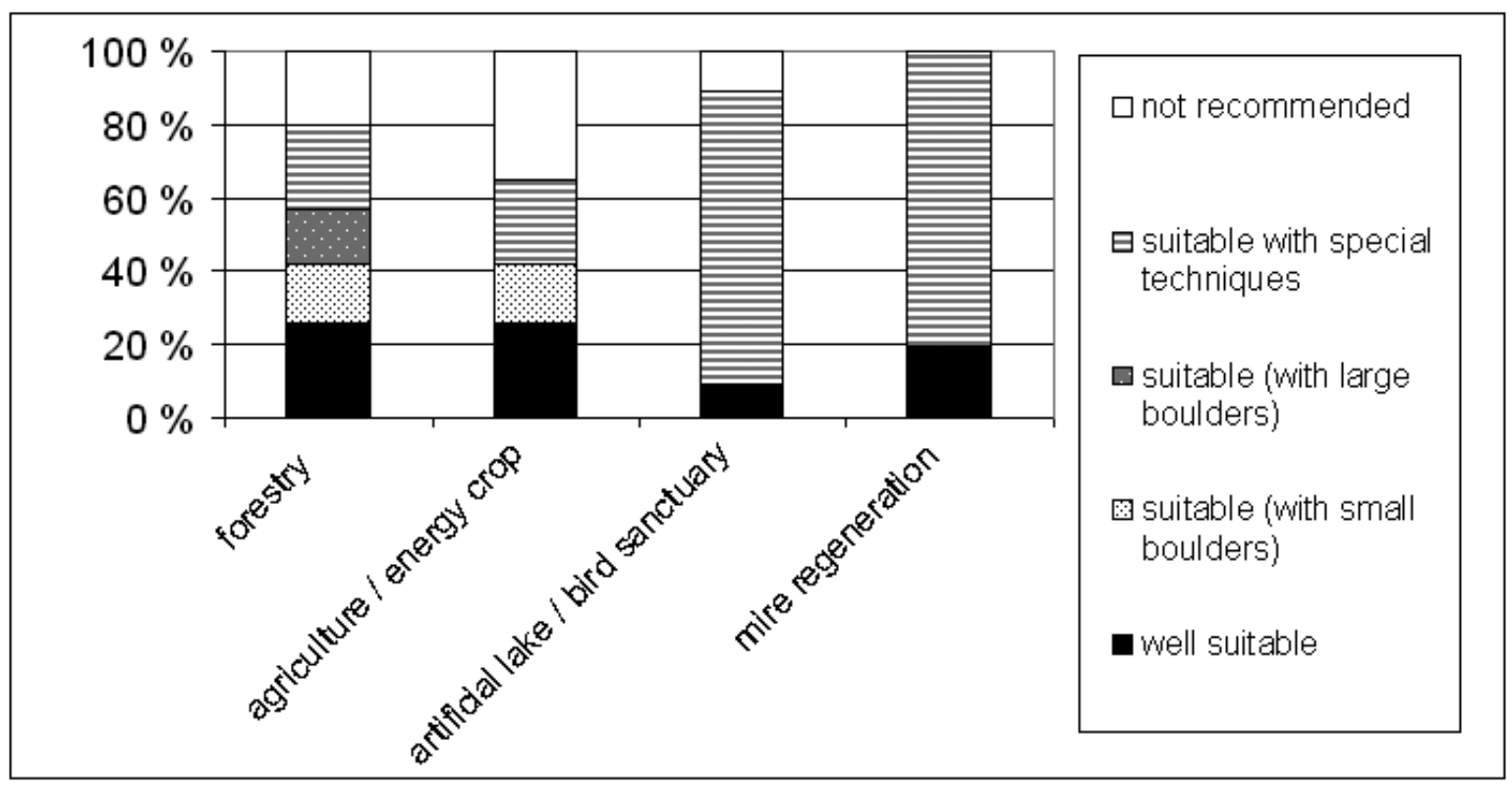

Fig. 3. After-use recommendations for Finnish cut-over peatlands.

\subsubsection{Scenario I, "Future according to current land-use"}

Future choices related to after-use are also going to affect on carbon balance. Scenario 1 was the first future land-use scenario for current active peat production areas together with the areas released from production still waiting for final after-use form. This scenario was based on the assumption that the percentages of the land-use forms stayed the same as they are. The resulting carbon accumulation rate 0.063 mil-

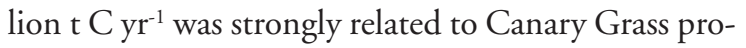
duction. Together with areas already in after-use this scenario's carbon accumulation rate was 0.074 million $\mathrm{t} \mathrm{C} \mathrm{yr}^{-1}$. (Fig. 4).

\subsubsection{Scenario 2, "Forestry basis"}

For the second future land-use scenario, suitability related to mineral subsoils was important. Forestry was the main focus and this scenario was called "Forestry basis". Forestry covered $80 \%$ and mire regeneration $20 \%$. All areas suitable for forestry (with any reason- able techniques) were calculated as forestation sites and all areas not suitable for forestry as mire regeneration sites. Forestry covered all areas without limitations related to topography or sulphur, even the very coarse and very fine sediments needing a peat layer as compensation for their poor features were included to the forestry area. In this scenario the annual Cfixation turned out to be approximately 0.089 million tonnes. If the carbon accumulation in the areas already in final after-use forms was added to this scenario, the carbon accumulation rate would be 0.100

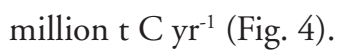

\subsubsection{Scenario 3, "Energy crop basis"}

Scenario 3 was the "Energy-crop basis". All areas suitable for agriculture (with any reasonable techniques) were taken to Canary Grass production (65\%). This included all areas without limitations related to topography, large boulders and sulphur, even the very coarse and very fine sediments needing a peat layer as compensation for their poor features were includ- 


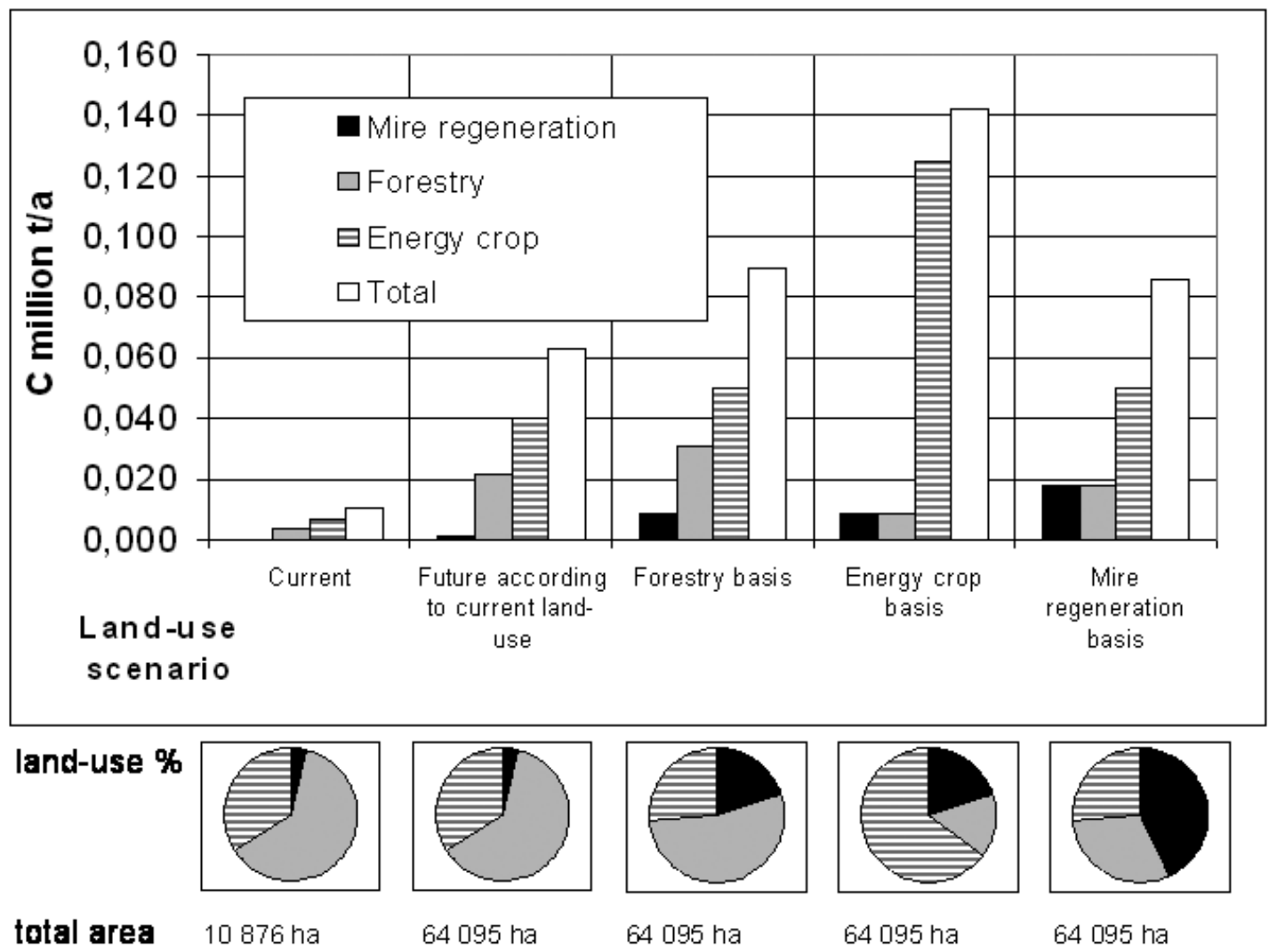

Fig. 4. Generalised annual carbon accumulation in different after-use scenarios (without carbon emission data from the same sites).

ed. Tills with large boulders (15\%) were used for forestry. There was $20 \%$ left for mire regeneration. In Scenario 3 the current peat production area together with released areas waiting for final after-use form fixated 0.142 million t $\mathrm{C} \mathrm{yr}^{-1}$. Together with areas already in after-use this resulted the carbon accumulation rate 0.152 million $\mathrm{t} \mathrm{C} \mathrm{yr}^{-1}$ (Fig. 4).

\subsubsection{Scenario 4, "Mire regeneration basis"}

"Mire regeneration basis" was a land-use scenario taking into account the subsoil recommendations very carefully. Energy crop production covered $26 \%$ of the area, the area best suitable for agriculture. The till areas well suitable for forestry covered $31 \%$ of all areas. The last $43 \%$ was used for mire regeneration. In Scenario 4 the current peat production area together with released areas waiting for final after-use form was calculated to accumulate 0.086 million $\mathrm{t} \mathrm{C} \mathrm{yr}^{-1}$. Together with areas already in after-use this resulted the carbon accumulation rate 0.096 million $\mathrm{t} \mathrm{C} \mathrm{yr}^{-1}$ (Fig. 4).

\section{Discussion}

Suitability to the different after-use forms did not meet the current after-use statistics. This could partly be explained by the fact that in many cases the deepest parts of the peatlands included the most sensitive or finest sediments - and places most difficult to drain. Deepest parts are usually also released last from the production: in many cases they still are in production even in older production sites. Some of the ear- 
liest after-use applications were also very experimental and the most suitable after-use form in relation to mineral subsoil was not always chosen. In some cases the after-use has already been planned in the phase of making rental contracts. Mire regeneration and other wetland applications are likely to get more volume in the long run when more of the deepest parts of peat production sites get released. Some of these areas are dried during peat production by pumping and ending pumping will mean flooding. This means also that the land-use scenario "Future according to current land-use" is not a very realistic scenario.

Many of the very fine and compact sediments were found in the middle of pool-forming sites, total $9 \%$ of all the mineral subsoils. Detailed flooding probabilities after peat production and exact pump dried area were not studied. Flooding situation may be in some cases expected also in a non-pool-forming site and it is not unavoidable in all pool-forming sites. Flooding can also be created artificially. Also coarser silts were found on so called pool-forming sites, but only ones with over $90 \%$ of fine particles were classified as after-use limiting mineral subsoils. If all clays and silts found in the middle of these "lake-like" pool-forming basins were calculated, they would actually cover $14 \%$ of the total area.

Agriculture and energy crop production have taken a strong position in cut-over sites after-use. This is likely to lead to maximum possible use of cut-over sites in Phalaris growing.

Differences in nutrient concentration standard deviations were found between groups $<15 \%$ and $15-$ $19.99 \%$ of fine material and differences in nutrient concentration medians between $15-19.99 \%$ and 20 $-30.99 \%$ of fine material. This supported the original limit value presented by Aro \& Kaunisto (1998), according to which reasonable growing conditions would exist on areas with mineral subsoils with minimum $15-20 \%$ of fine material.

In this study, a level of $15 \%$ of fine material in mineral subsoil was used as a coarse limit value for suitability to agriculture and forestry for all areas. Local applications of this limit value might have been useful, because nutrient concentrations of coarse sediments vary between different geological areas. In some areas sediments with $15 \%$ of fine material are more nutrient rich than in other areas (Picken, 2005). Though suitability estimations based on this study give direction but are not definite limit values. Poor suitability can be compensated by fertilisation and other techniques (Aro \& Kaunisto, 1998). Anyhow natural nutrient content of the mineral subsoil (exchangeable $\mathrm{Ca}, \mathrm{Mg}$ and $\mathrm{K}$ ) was also in this study related to the fine material percentage.

For future it could be recommended to use a uniform mapping practise in after-use planning. This would help to share information of general experiences, productivity and environmental effects of after-use. The better the existing circumstances on each site are known, the better the experiences can be utilized in new cases.

Calculated carbon fixation results can vary strongly depending on different carbon fixation rates available for forestation (in literature). Carbon accumulation rates vary also in mire regeneration and numbers presented in this study would have been higher if actual Sphagnum farming was included instead of only basic flooding methods in mire regeneration. The carbon accumulation rates in after-use sites represent only short-term carbon accumulation rates. It is also important to remember, that respiration has not been taken into account. In real life also the methane emissions affect strongly to carbon balance. In mire regeneration Tuittila et al. (2000) have documented methane fluxes on Spahgnum surfaces and bare peat, fluxes were between $-0,1$ and $0,3 \mathrm{mg} \mathrm{C} \mathrm{m}^{-2} \mathrm{~h}^{-1}$. In Lakkasuo mire complex methane emissions have been over $30 \mathrm{~g}$ $\mathrm{CH}_{4} \mathrm{~m}^{-2} \mathrm{yr}^{-1}$ in Carex-rich fen parts (Nykänen et al., 1998) and $2-5 \mathrm{~g} \mathrm{CH}_{4} \mathrm{~m}^{-2} \mathrm{yr}^{-1}$ in more Sphagnumrich parts (Laine et al., 2002).

Studying carbon accumulation only on the afteruse sites gives only one part of the picture of carbon balance related to the use of peatlands. If the total carbon balance in Finnish peatlands was estimated in relation to peat use, also the accumulation on pristine mires and afforested peatlands could be taken into consideration.

More detailed work would be needed to predict 
carbon balance related to the after-use. Also carbon emissions should be included to this type of calculations in the future - as information quantity in this front keeps increasing.

\section{Conclusions}

Economical interests and mineral subsoil suitability may lead to a situation where many Finnish cut-over peatlands become forested or used for energy crop growing. The cutover area clearly suitable for forestation covered $57 \%$ of the study area. The area well suitable for agriculture or energy crop growing covered 26, but up to $42 \%$ would be suitable if boulder-poor tills were included. Same areas were usually considered suitable for both forestry and agriculture - though more and larger boulders were accepted for forestry. Even larger areas might be usable for these purposes in some conditions.

Based on this study $11 \%$ of the area was recommended for mire regeneration because of relatively sulphur rich mineral subsoils. On top of this $9 \%$ of the area was recommended for reflooding because of fine mineral subsoils on pool-forming locations. In pool-forming areas reflooding could mean both mire regeneration and bird sanctuaries (artificial lakes).

After excluding areas recommended for agriculture or forestry and for mire regeneration or bird sanctuaries another $23 \%$ of the area remains unspecified. This $23 \%$ includes very coarse and very fine mineral subsoils and their economical use possibilities can probably be adjusted depending on factors related to the remaining peat layer. These sites can also be used for example for mire regeneration, especially with artificial adjustment of the water table.

Natural nutrient content (exchangeable $\mathrm{Ca}, \mathrm{Mg}$ and $\mathrm{K}$ ) followed the fine material percentage of the mineral subsoil. Phosphorus, nitrogen and sulphur (water-soluble) did not occur specially in any coarseness level. Both EC and $\mathrm{pH}$ of the mineral correlated with the presence of sulphur.

Knowing the relevant features of the mineral subsoil of each peat production site is essential in decision making - especially when the remaining peat layer is very thin. Based on this study minimum analysis recommended for mineral subsoils would be $\mathrm{pH}$, sulphur content and fine material $(<0.06 \mathrm{~mm})$ percentage. Other relevant elements are calcium, magnesium and potassium. Chemical and physical data (mean features, minimums and maximums) of this study can be used as a reference data when individual site's features being estimated for after-use planning.

In different land-use scenarios based on the mineral subsoil suitability the annual carbon fixation values

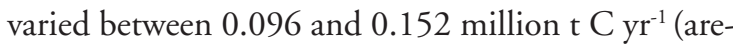
as in after-use, released from peat production and in peat production 2004). The most optimistic number was calculated in a scenario rich in energy crop production, but it is important to realise, that these crops would be harvested and majority of their parts above the ground used annually. The annual carbon accumulation value would be smaller $(0.074$ million $\left.\mathrm{t} \mathrm{C} \mathrm{yr}^{-1}\right)$, if the percentages of land-use forms would remain the same as now in the future. These values did not include the carbon emissions in different land-use forms.

\section{Acknowledgements}

Members of Vapo Oy staff are acknowledged for analysis services and support during this work, especially Dr. Pirkko Selin, Veijo Klemetti and Markku Herranen, also summer assistants (1998, 1999 and 2002) are acknowledged for their help in the field work and in documentation. Dr. Veli-Pekka Salonen (University of Helsinki) is acknowledged for his advice and comments in all later study phases. Dr. Marja-Liisa Räisänen and Riitta Korhonen are acknowledged for reviewing the article, with valuable comments. Many good advices have been received also from several other people during the manuscript editing. Anthony Picken is acknowledged for his help related to English language.

\section{References}

Aro, L, Kaunisto S. \& Saarinen M., 1997. Suopohjien metsitys. Hankeraportti 1986-1995. Metsäntutkimuslaitoksen tiedonantoja 634, 51 p.

Aro, L \& Kaunisto, S., 1998. Forestry use of peat cutaway areas in Finland. The Spirit of Peatlands, 30 years of the International Peat Society. International Peat Society, Jyväskylä, Finland, 185-186. 
Heinonen, R. Hartikainen, H., Aura, E., Jaakkola, A. ja Kemppainen, E., 1992. Maa, viljely ja ympäristö, WSOY, Porvoo, Finland, 334 p.

Huttunen, J.T., Nykänen, H. \& Martikainen, P.J., 2004. Reed Canary Grass cultivation on cut-away peatlands and the ecosystem carbon balance. Wise use of Peatlands. Proceedings of the $12^{\text {th }}$ International Peat Peat Congress. International Peat Society, p. 977-982.

Kaunisto, S. \& Aro, L., 1998. Suopohjat metsätaloudessa. In: Vasander, H. (ed) Suomen suot, Suoseura ry., p. $134-134$.

Koljonen, T. (ed.), 1992. The Geochemical Atlas of Finland, Part 2: Till. Geological Survey of Finland, 218 p.

Laine, J., Komulainen, V., Laiho, R., Minkkinen, K., Rasinmäki, A., Sallantaus, T., Sarkkola, S., Silvan, N., Tolonen, K., Tuittila, E., Vasander, H. \& Päivänen, J., 2002. Lakkasuo-opas suon ekosysteemiin. University of Helsinki, Department of Forest Ecology Publications, 120 p.

Lohila, A., Aurela, M., Aro, L. \& Laurila, T., 2004. Effects of afforestation on the $\mathrm{CO}_{2}$ balance of an agricultural peat soil. Wise use of peatlands. Proceedings of the $12^{\text {th }}$ International Peat Conference. International Peat Society, p. 145-149.

Lötjönen, P., 2004. After-use predictions for Finnish cutover peatlands-based on the characteristics of under-lying mineral soils. Proceedings of the $12^{\text {th }}$ International Peat conference. International Peat Society, 385-390.

Lötjönen, P., Klemetti, V. \& Selin, P., 2002. Geological factors affecting the restoration and reclamation of Finnish cut-over bogs. Proceedings of the International Peat Conference. Peat in Horticulture, Quality and Environmental Challenges. International Peat Society, p. 178-186.

Lötjönen, P., 1999. Soiden pohjamaatutkimus 1998-1999, loppuraportti. Vapo Oy, Internal report, 53+12 p.

Mäkilä, M., 1997. Holocene lateral expansion, peat growth and carbon accumulation on Haukkasuo, a raised bog in southeastern Finland. Boreas 26, 1-14.

Nykänen, H., Alm, J., Silvola, J., Tolonen, K. \& Martikainen, P. J., 1998. Methane fluxes on boreal peatlands of different fertility and the effect of long-term experimental lowering of the water table on flux rates. Global Biochemical Cycles 12, 53-69.

Picken, P., 2005. The characteristics of mineral subsoils of Finnish cut-over peatlands related to different geological areas. Suo (Mires and peat) 56, 57-67.

Pitkänen, A., Turunen, J. Tolonen K., 1999. The role of fire in the carbon dymamics of a mire, eastern Finland. The Holocene 9, 453-462.

Puuronen, M., Mikkonen, T. \& Käyhkö, V., 1998. Energiakasvien (mm. ruokohelpi) viljelykokeiluturvesuoalueilla ja saatavan bioenergian soveltuvuus eri käyttökohteisiin. Bioenergian tutkimusohjelman julkaisuja 18 (II), 135-142.

Roderfelt, H., Vasander, H. \& Tolonen, K., 1994. Differences in carbon accumulation of two cut-over peatlands in Finland. The Finnish Research Programme on Climate Change, $2^{\text {nd }}$ Progress Report. Publication of the Academy of Finland, 315-320.

Selin, P., 1999. Turvevarojen teollinen käyttö ja suopohjien hyödyntäminen Suomessa / Industrial use of peatlands and the re-use of cut-away areas in Finland. University of Jyväskylä, Jyväskylä, Finland, 239 p.

Silpola, J., 2004. Katsaus kesän tuotantoon Suomessa ja muualla maailmassa. Turvepäivä -seminar, 26.10.2004. Turveteollisuusliitto (Association of Finnish Peat Industries), $1 \mathrm{p}$.

Silpola, J. \& Tuomanen, S., 2005. Unpublished statistics of land-use in peat production in Finland. Association of Finnish Peat Industries.

Siira, J. (ed), 1996. Limingan Hirvinevan turvetuotantoalueelle kaivetun tekolammen veden laatu ja eliöstön kehitys kolmen ensimmäisen vuoden aikana. Perämeren tutkimuslaitoksen julkaisuja 6, University of Oulu, 112 p.

Tolonen, K. \& Turunen, J., 1996a. Accumulation rates of carbon in mires in Finland and implications for climate change. The Holocene 6, 171-178.

Tolonen, K. \& Turunen, J., 1996b. Carbon accumulation in mires in Finland. Nortern peatlands in global climatic change. Proceedings of the international workshop held in Hyytiälä, Finland, 8-12 October 1995, SILMU, The Finnish Research programme on climatic change, Publications of the academy of Finland 1/96, 250-255.

Tolonen, K., Turunen, J., Alm, J., Korhola, A., Jungner, H. \& Vasander, H., 1996. Accumulation of carbon in northern mire ecosystems. SILMU, The Finnish Research programme on climatic change, Final Report, Publications of the Academy of Finland 4/96, 75-383.

Tolonen, K., Davis, R.B. \& Widoff, L.S., 1985. Peat accumulation rates in selected Maine peat deposits. Maine Geological Survey, Bulletin 33.

Tuittila, E., Komulainen, V., Vasander, H. \& Laine, J., 1999. Restored cut-away peatland as a sink for atmospheric $\mathrm{CO}_{2}$. Oecologia 120, 563-574.

Tuittila, E-S., Vasander, H. \& Laine, J., 2000. Impact of Sphagnum re-introduction on the carbon dynamics of a cut-away peatland. In: Tuittila, E-S., 2000. Restoring vegetation and carbon dynamics in a cut-away peatland. Publications in Botany, University of Helsinki, 30.

Wind-Mulder, H.L. \& Vitt, D.H., 2000. Comparisons of water and peat chemistries of a post-harvested and undisturbed peatland with relevance to restoration. Wetlands 20, 616-628.

Virtanen, K., Hänninen, P., Kallinen, R., Vartiainen, S., Herranen, T. \& Jokisaari, R., 2003. Suomen turvevarat 2000. Geological Survey of Finland, Tutkimusraportti $156,101 \mathrm{p}$.

Yli-Halla, M., 2003. Pitääkö kaikkein happamimmat sulfaattimaat poistaa viljelystä? Summary: Should the cultivation of the most acidic sulphate soils be stopped? Suo (Mires and peat) 54, 143-148. 